\title{
Algoritma Naïve Bayes Berbasis Forward Selection Untuk Prediksi Bimbingan Konseling Siswa
}

\author{
M. Rudi Fanani ${ }^{1}$, Syamsul Ma'Arif ${ }^{2}$ \\ ${ }^{1}$ Institut Teknologi dan Sains Nahdlatul Ulama Pekalongan \\ 2Universitas Islam Nahdlatul Ulama Jepara \\ m.rudifanani@ymail.com¹ ${ }^{1}$,syamsulmaarif@unisnu.ac.id²
}

\begin{abstract}
Guidance and counseling activities in schools are a way to help students develop personalities, social attitudes, learning, career development and planning. Guidance and Counseling activities also play a role in addressing the deviant behavior of the students shown by the students both within the scope of the school and also outside of school. In determining counseling guidance activities, counseling guidance teachers can provide an assessment of the extent to which student behavior is improved in school. However, the determination of guidance and counseling recommendations is inaccurate because it must be based on knowledge and processing the amount of data available so that a calculation is needed that applies the prediction method with data mining techniques. One of the data mining techniques is Naïve Bayes which uses classification techniques, which are able to produce an accuracy value of $94.55 \%$ and also in research applying the selection feature which is used as a feature selection that affects the classification in order to improve accuracy. The selection feature used is Forward Selection which is able to increase accuracy to $94.84 \%$ by removing some features that are not relevant to classification and making better results than using the Naïve Bayes method alone.
\end{abstract}

Keywords: Guidance, Counseling, Forward, Selection, Classification

\begin{abstract}
Abstrak
Kegiatan bimbingan dan konseling di sekolah adalah cara membantu siswa dalam mengembangkan kepribadian, sikap sosial, pembelajaran, pengembangan karir dan perencanaan. Kegiatan Bimbingan dan Konseling juga berperan dalam menyikapi perilaku menyimpang para siswa yang ditunjukkan para siswa baik masih berada dalam limgkup sekolah dan juga luar sekolah. Dalam menentukan kegiatan bimbingan konseling, guru bimbingan konseling dapat memberikan penilaian sejauh mana peningkatan perilaku siswa di sekolah. Namun penentuan rekomendasi bimbingan dan konseling kurang akurat dikarenakan harus berdasarkan pengetahuan dan pengolahan banyaknya data yang ada sehingga diperlukan sebuah perhitungan yang menerapkan metode prediksi dengan teknik data mining. Salah satu teknik data mining adalah Naïve Bayes yang menggunakan teknik klasifikasi, yang mampu menghasilkan nilai akurasi sebesar $94.55 \%$ dan juga dalam penelitian menerapkan fitur seleksi yang digunakan sebagau pemilihan fitur yang berpengaruh terhadap klasifikasi guna meningkatkan akurasi. Fitur seleksi yang digunakan adalah Forward Selection yang mampu meningkatkan akurasi menjadi 94.84\% dengan membuang beberapa fitur yang tidak relevan terhadap klasifikasi dan menjadikan hasil yang lebih baik daripada menggunakan metode Naïve Bayes saja.

Kata kunci: Bimbingan Konseling; Forward Selection; Klasifikasi; Naïve Bayes; Prediksi.
\end{abstract}

\section{Pendahuluan}

Kegiatan bimbingan dan konseling di sekolah adalah cara membantu siswa dalam mengembangkan kepribadian, sikap sosial, pembelajaran, pengembangan karir dan perencanaan. kegiatan bimbingan dan konseling memberikan cara mengembangkan diri siswa secara pribadi dan kelompok, yang menyesuaikan dengan, potensi, perkembangan, bakat, kebutuhan, minat, dan lain sebagainya. Kegiatan ini juga memberikan bantuan untuk mengatasi hambatan juga kelemahan dan masalah yang dihadapi siswa. Awal mula diselenggarakan bimbingan dan konseling di sekolah bukan dari 
ketentuan dari atas ataupun landasan hukum, tapi yang lebih penting yaitu yang berhubungan dengan cara memfasilitasi siswa yang selanjutnya disebut dengan konseli, agar potensi diri siswa dapat berkembang atau perkmbangan tersebut dapat dicapai (berhubungan aspek emosi, intelektual, fisik, moral dan sosial) [1].

Kegiatan bimbingan dan konseling tidak bisa dipisahkan dari bidang pendidikan. Dalam melaksanakan tidak boleh secara bebas dan gampang, banyak kekeliruan yang timbul dalam kegiatan bimbingan dan konseling yang sudah berjalan, banyak yang beranggapan polisi dalam sekolah merupakan kegiatan dari bimbingan dan konseling maupun anggapan yang berbeda dari fungsi kegiatan bimbingan dan konseling. semua aturan pendidikan yang ada harus dilengkapi dengan Bimbingan dan konseling yang ada di sekolah, untuk melancarkan fungsi serta tugas pendidikan dengan benar, sehingga para penyelenggara pendidikan mempunyai relasi yang baik, secara umum diperlukan penanganan individu untuk mencapai tujuan pendidikan yang lebih baik. Tidak akan tercapai tujuan pendidikan jika hanya dengan cara pengajaran oleh guru, tetapi juga diperlukan program kegiatan bimbingan dan konseling yang terdapat didalam PP No. 38/1992 Pasal I ayat 2 tentang tenaga Kependidikan, yang berisi: "Tenaga pendidik adalah tenaga kependidikan yang bertugas membimbing, mengajar dan atau melatih peserta didik" [2].

Dari penjelasan di atas, jelas bahwa melakukan prediksi bimbingan konseling diperlukan sebuah perhitungan yang menerapkan metode prediksi dan juga merupakan hal yang penting bagi sekolah untuk menentukan kebijaksaan strategis, dan sekolah bisa menggunakan mekanisme pendukung seperti pengawasan, nasihat, orientasi dan lain-lain.

Naïve Bayes adalah perhitungan probabilitas dengan metode pengklasifikasian. Model ini mudah untuk dibangun dan tidak complicated, sehingga dianggap tepat untuk database yang berukuran kecil sampai berukuran besar. Algoritma Naïve Bayes menghitung probabilitas kejadian masa datang dari kejadian sebelumnya dimana masing-masing variabel dianggap tidak saling tergantung [3]. Kelebihan dari algoritma Naïve Bayes adalah sederhana tapi mempunyai akurasi yang tinggi meskipun menggunakan data yang sedikit [4]. Sedangkan kelemahan dalam Naive Bayes, yaitu prediksi hasil probabilitas berjalan tidak optimal serta kurangnya pemilihan fitur yang relevan terhadap klasifikasi sehingga akurasi menjadi rendah Hal tersebut dapat diatasi dengan cara pemilihan fitur yang berguna untuk meningkatkan akurasi [5]. Algoritma Forward Selection merupakan salah satu seleksi fitur yang dilakukan sebelum pemrosesan dalam klasifikasi yang terbukti efektif digunakan untuk memecahkan masalah pemilihan fitur yang relevan dalam suatu data Forward Selection dijalankan mengunakan pemilihan fitur yang relevan untuk data yang berpengaruh terhadap hasil klasifikasi. Juga dalam mengurangi dimensi data dan sebagai peningkatan efisien dan efektifitas kerja algoritma klasifikasi [6].

\section{Tinjauan Pustaka}

\section{a. Pengertian Bimbingan}

Arti bimbingan adalah pertolongan maupun bantuan ditujukan untuk seseorang guna kesulitan dalam kehidupan bisa diatasi maupun dihindari, seseorang maupun banyak orang tersebut kesejahteraan dalam hidupnya bisa tercapai [7].

\section{b. Pengertian Konseling}

Pengertian pelayanan konseling di sekolah merupakan usaha membantu peserta didik dalam pengembangan kehidupan pribadi, kehidupan sosial, kegiatan belajar, serta perencanaan dan pengembangan karir Pelayanan ini juga membantu mengatasi kelemahan dan hambatan serta masalah yang dihadapi peserta didik [7].

\section{c. Bidang-Bidang Bimbingan Konseling}

Pembidangan dalam pelaksanaan bimbingan dan konseling di sekolah dengan ragam bimbingan empat bidang yakni a) Pengembangan kehidupan pribadi, Pengembangan kehidupan sosial, Pengembangan kemampuan belajar, Pengembangan karir [7].

\section{d. Jenis-Jenis Kegiatan Bimbingan Konseling}

Jenis-jenis layanan dalam bimbingan dan konseling yakni: a) Orientasi yaitu layanan yang membantu peserta didik memahami lingkungan baru, b) Informasi, yaitu layanan yang membantu peserta didik menerima dan memahami berbagai informasi, c) Penempatan dan Penyaluran, yaitu layanan yang membantu peserta didik memperoleh penempatan dan penyaluran yang 
tepat di dalam kelas, d) Penguasaan Konten, yaitu layanan yang membantu peserta didik menguasai konten tertentu, e) Konseling Perorangan, yaitu layanan yang membantu peserta didik dalam mengentaskan masalah pribadinya, f) Bimbingan Kelompok, yaitu layanan yang membantu peserta didik dalam kemampuan hubungan sosial, $h$ ) Konsultasi, yaitu layanan yang membantu peserta didik dan atau pihak lain dalam memperoleh wawasan [7].

\section{f. Data Mining}

Data mining adalah kegiatan menemukan pola yang menarik dari data dalam jumlah besar, data dapat disimpan dalam database, data warehouse, atau penyimpanan informasi lainnya. Data mining berkaitan dengan bidang ilmu-ilmu lain, seperti database system, data warehousing, statistik, machine learning, information retrieval, dan komputasi tingkat tinggi. Selain itu, data mining didukung oleh ilmu lain seperti neural network, pengenalan pola, spatial data analysis, image database, signal processing[8].

\section{g. Klasifikasi}

Klasifikasi adalah proses untuk menemukan model atau fungsi yang menjelaskan atau membedakan kelas data, dengan tujuan untuk dapat memperkirakan kelas dari suatu objek yang labelnya tidak diketahui [9].

\section{h. Naïve Bayes}

Naïve Bayes adalah suatu metode yang digunakan untuk dapat memperkirakan atau memprediksi suatu class dari suatu objek yang kelasnya tidak diketahui dari masing-masing kelompok atribut yang ada, dan menentukan class mana yang paling optimal berdasarkan pengaruh yang didapat dari hasil pengamatan. Klasifikasiklasifikasi Bayes adalah klasifikasi statistik yang dapat digunakan untuk memprediksi probabilitas keanggotaan suatu class [10]. Prediksi Bayes didasarkan pada formula teorema Bayes dengan formula umum sebagai berikut:

$$
\begin{aligned}
& \qquad P(A \mid B) \frac{P(B \mid A) P(A)}{P(B)} \\
& \text { Keterangan: } \\
& B \quad=\text { Data dengan class yang belum }
\end{aligned}
$$
diketahui

$$
\begin{gathered}
A \quad=\text { Hipotesis data } B \text { merupakan } \\
\text { suatu class spesifik } \\
P(A \mid B)=\text { Probabilitas } A \text { berdasarkan }
\end{gathered}
$$$$
\text { kondisi } B
$$$$
\text { kondisi } A
$$

$$
P(B \mid A)=\text { Probabilitas } B \text { berdasarkan }
$$

$$
P(A) \quad=\text { Probabilitas dari } A
$$$$
P(B) \quad=\text { Probabilitas dari } B
$$

Tahapan Algoritma Naïve Bayes:

1. Baca data training

2. Hitung jumlah class.

3. Hitung jumlah kasus yang sama dengan class yang sama (Probabilitas).

4. Kalikan semua nilai hasil sesuai dengan data baru yang dicari class-nya. Bandingkan hasil class pilih dengan nilai terbesar.

\section{i. Seleksi Fitur}

Seleksi fitur merupakan salah satu tahapan praproses yang berguna terutama dalam hal meningkatkan hasil akurasi, menghilangkan data yang tidak relevan, juga mengurangi dimensi data. Definisi seleksi fitur adalah mengamati sekumpulan fitur kemudian dipilih beberapa fitur yang mampu memberikan hasil yang terbaik untuk klasifikasi. Terapat dua hal dalam seleksi fitur yang menggunakan pendekatan machine learning yaitu memilih fitur yang akan digunakan dan menjelaskan secara konsep bagaimana mengkombinasikan fitur-fitur tersebut untuk menghasilkan konsep yang benar atau hasil yang sesuai [11].

\section{j. Forward Selection}

Forward selection adalah salah satu prosedur bertahap yang bertujuan untuk menambah variabel yang dikendalikan satu per satu ke dalam persamaan, Forward selection dimulai dengan fitur himpunan kosong lalu menambahkan fitur yang terpakai pada putaran pertama, semua fitur dievaluasi masing-masing. Salah satu fitur ditambahkan pada fitur himpunan yang merupakan bagian dari fitur sebelumnya dan juga fitur yang baru dibuat, lalu dievaluasi kembali. Untuk mengurangi jumlah evaluasi, hanya subset fitur terbaik yang disimpan seperti gambar 2.1 [12]. 


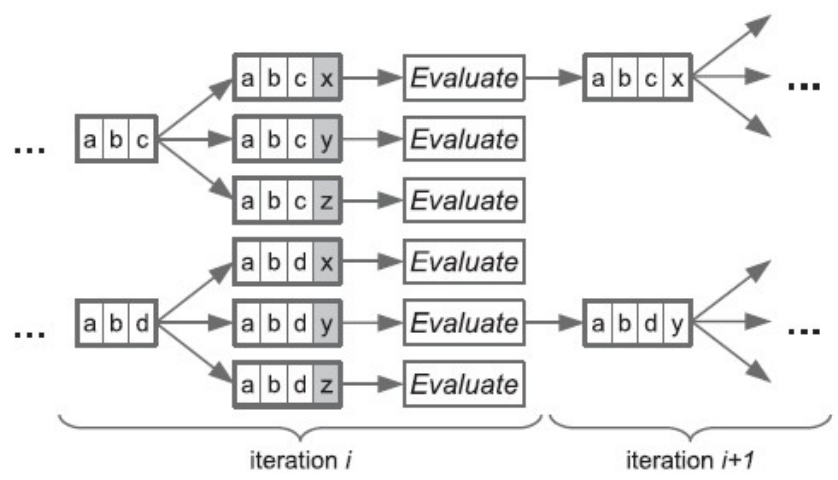

\section{Gambar 2.1 Metode Forward Selection}

Data yang di-training dilakukan secara bertahap yakni dimulai dari 1 variabel sampai pada tingkat atau jumlah variabel yang menghasilkan performa atau nilai akurasi paling baik atau error terkecil. Misalnya pada pengujian data dengan 2 variabel menghasilkan erorr lebih kecil dan ketika diujikan lagi dengan 3 variabel dan menghasilkan nilai erorr lebih besar dibandingkan dengan 2 variabel maka error terkecil didapatkan pada variabel ke 2 yang berarti variabel kedua signifikan, proses dihentikan bila semua variabel independen sudah diujikan. Algoritma Forward Selection akan diujikan pada setiap data, mulai dari data 1 variabel periode sampai pada data 10 variabel periode untuk dibandingkan data mana yang menghasilkan akurasi yang paling baik [13].

\section{k. Backward Elimination}

Backward Elimination merupakan kebalikan dari algoritma Forward Selection yaitu sama dalam hal menghilangkan atribut-atribut yang tidak relevan, Metode Backward bekerja dengan memasukkan semua variabel yang ada dan mengeluarkan satu per satu variabel prediktor yang tidak signifikan berdasarkan hasil niai akurasi tertinggi atau error terkecil dan dilakukan terus menerus sampai tidak ada variabel prediktor yang tidak signifikan [14].

\section{K-Fold Cross Validation}

Cross Validation adalah salah satu metode yang dipakai untuk memperoleh parameter terbaik menggunakan cara pengujian besarnya error pada data testing. Cross Validation membagi data secara acak kedalam $k$ bagian dengan ukuran yang sama dan masingmasing bagian akan dilakukan proses klasifikasi Secara umum pengujian nilai dilakukan sebanyak 10 kali untuk memperkirakan akurasi estimasi. Dalam penelitian yang digunakan berjumlah 10 atau 10-fold Cross Validation Penggunaan 10 fold ini dianjurkan karena merupakan jumlah fold terbaik untuk uji validitas seperti pada gambar 2.2 [15]. 


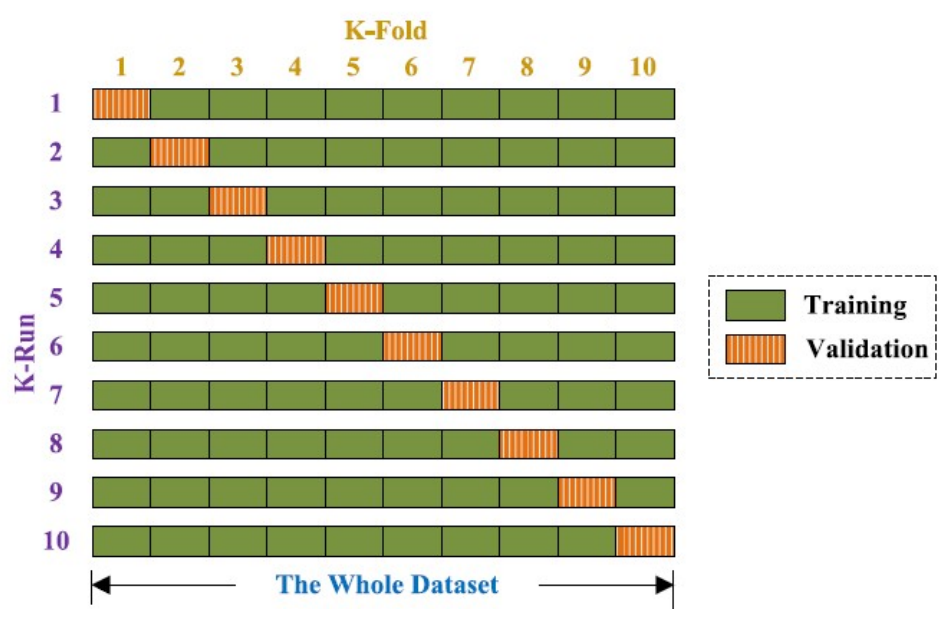

Gambar 2.2 Metode 10-Fold Cross Validation

\section{m. Confusion Matrix}

Penelitian ini menggunakan pengukuran evaluasi yaitu confusion matrix yang mempunyai tujuan guna mempermudah dalam analisis performa algoritma, dikarenakan confusion matrix bias menampilkan informasi berbentuk angka, sehingga bias dilkaukan perhitungan rasio keberhasilan klasifikasi. Confusion matrix adalah salah satu alat ukur berbentuk matrik $2 \times 2$ yang dipakai guna memperoleh jumlah ketepatan klasifikasi dataset terhadap satu kelas dengan kelas lain pada algoritma yang dipakai seperti pada tabel 2.1 [16].

Tabel 2.1 Confusion Matrix

\begin{tabular}{|c|c|c|c|}
\hline CLASSIFICATION & & redicted Class & \\
\hline \multirow{5}{*}{ OBERVED CLASS } & & Class $=$ Yes & Class $=$ No \\
\hline & \multirow[t]{2}{*}{ Class = Yes } & A & $\mathrm{B}$ \\
\hline & & (True Positive $=$ TP) & (False Negative $=\mathrm{FN}$ ) \\
\hline & \multirow[t]{2}{*}{ Class $=$ No } & $\mathrm{C}$ & $\mathrm{D}$ \\
\hline & & (False Positive=FP) & (True negative=TN) \\
\hline
\end{tabular}

Keterangan :

$T P=$ Prediksi positif yang positif

$F N=$ Prediksi positif yang negatif

$F P=$ Prediksi negatif yang positif

$T N=$ Prediksi negatif yang negative Untuk menghitung nilai dari precision:

$$
\text { Precision }=\left(\frac{D}{C+D}\right)=\frac{T N}{F P+T}
$$

Sedangkan nilai dari recall:

$$
\text { Recall }=\left(\frac{D}{B+D}\right)=\frac{T N}{F N+T}
$$

Dan nilai accuracy:
Accuracy $=\left(\frac{A+D}{A+B+C+D}\right)=\frac{T P+T}{T P+T N+F P+F N}$

\section{Metode Penelitian}

a. Pengumpulan Data

Penelitian ini menggunakan data berupa dokumen laporan bimbingan konseling siswa SMK NU Ma'arif Tirto berisi 329 record dan terdiri dari variabel hubungan sosial dan berorganisasi, keadaan kehidupan ekonomi, rekreasi dan hobi, kehidupan keluarga, agama dan moral, kesehatan, pribadi, penyesuaian sekolah, penyesuaian kurikulum, dan masa depan pendidikan. Dokumen ini akan digunakan untuk 
data eksperimen memprediksi bimbingan konseling.

Jenis penelitian ini adalah eksperimen. Penelitian ini menggunakan data sekunder. Data sekunder berupa data bimbingan konseling yang dilakukan guru BK Bawon Sulastri yang telah berpengalaman dan berkompeten di bidangnya selama 8 tahun, tetapi tidak diterbitkan. Dari jumlah 329 record, 102 record menghasilkan label Diharuskan Konseling dan 227 record menghasilkan Tidak diharuskan konseling.

\section{b. Pengolahan Data Awal}

Untuk memberikan gambaran yang jelas tentang data dalam penelitian ini, maka peneliti memberikan definisi terhadap variabel yang akan diangkat dalam penelitian ini agar pemahaman dan persepsi menjadi satu seperti dijelaskan dalam tabel 3.1:

Tabel 3.1 Penjelasan Variabel

\begin{tabular}{|l|l|l|}
\hline \multicolumn{1}{|c|}{ Nama Variabel } & \multicolumn{1}{|c|}{ Penjelasan/ Rincian Variabel } & \multicolumn{1}{c|}{ Indikator Penilaian } \\
\hline $\begin{array}{l}\text { Masalah Hubungan Sosial } \\
\text { dan Berorganisasi }\end{array}$ & $\begin{array}{l}\text { Faktor yang mempengaruhi } \\
\text { Masalah hubungan sosial dan } \\
\text { berorganisas }\end{array}$ & $\begin{array}{l}\text { Sangat Baik-Baik-Cukup Baik- } \\
\text { Cukup-Kurang-Kurang Sekali }\end{array}$ \\
\hline $\begin{array}{l}\text { Masalah Keadaaan } \\
\text { Kehidupan Ekonomi }\end{array}$ & $\begin{array}{l}\text { Faktor yang mempengaruhi } \\
\text { Masalah kehidupan ekonomi }\end{array}$ & $\begin{array}{l}\text { Sangat Baik-Baik-Cukup Baik- } \\
\text { Cukup-Kurang-Kurang Sekali }\end{array}$ \\
\hline Masalah Rekreasi dan Hobi & $\begin{array}{l}\text { Faktor yang mempengaruhi } \\
\text { Masalah Rekreasi dan Hobi }\end{array}$ & $\begin{array}{l}\text { Sangat Baik-Baik-Cukup Baik- } \\
\text { Cukup-Kurang-Kurang Sekali }\end{array}$ \\
\hline Masalah Kehidupan Keluarga & $\begin{array}{l}\text { Faktor yang mempengaruhi } \\
\text { Masalah Kehidupan Keluarga }\end{array}$ & $\begin{array}{l}\text { Sangat Baik-Baik-Cukup Baik- } \\
\text { Cukup-Kurang-Kurang Sekali }\end{array}$ \\
\hline Masalah Agama dan Moral & $\begin{array}{l}\text { Faktor yang mempengaruhi } \\
\text { Masalah Agama dan Moral }\end{array}$ & $\begin{array}{l}\text { Sangat Baik-Baik-Cukup Baik- } \\
\text { Cukup-Kurang-Kurang Sekali }\end{array}$ \\
\hline Masalah Kesehatan & $\begin{array}{l}\text { Faktor yang mempengaruhi } \\
\text { Masalah Pribadi }\end{array}$ & $\begin{array}{l}\text { Sangat Baik-Baik-Cukup Baik- } \\
\text { Cukup-Kurang-Kurang Sekali }\end{array}$ \\
\hline $\begin{array}{l}\text { Masalah Penyesuaian } \\
\text { Sekolah }\end{array}$ & $\begin{array}{l}\text { Faktor yang mempengaruhi } \\
\text { Masalah Penyesuaian Sekolah }\end{array}$ & $\begin{array}{l}\text { Sangat Baik-Baik-Cukup Baik- } \\
\text { Cukup-Kurang-Kurang Sekali }\end{array}$ \\
\hline $\begin{array}{l}\text { Masalah Penyesuaian } \\
\text { Terhadap Kurikulum }\end{array}$ & $\begin{array}{l}\text { Faktor yang mempengaruhi } \\
\text { Masalah Penyesuaian Terhadap } \\
\text { Kurikulum }\end{array}$ & $\begin{array}{l}\text { Sangat Baik-Baik-Cukup Baik- } \\
\text { Cukup-Kurang-Kurang Sekali }\end{array}$ \\
\hline $\begin{array}{l}\text { Masalah Masa Depan } \\
\text { Mendidikan }\end{array}$ & $\begin{array}{l}\text { Faktor yang mempengaruhi } \\
\text { Masalah Pribadi }\end{array}$ & $\begin{array}{l}\text { Sangat Baik-Baik-Cukup Baik- } \\
\text { Cukup-Kurang-Kurang Sekali }\end{array}$ \\
\hline Masalah Pribadi & Cukup-Kurang-Kurang Sekali \\
\hline
\end{tabular}

Tabel 3.1 merupakan penjelasan variabe dari dataset bimbingan dan konseling, untuk mendapatkan hasil indikator penilaian dari variabel, sebelumnya dilakukan penilaian pada tiap rincian variabel untuk menghasilkan ataupun mengetahui indikator penilaian akhir dari tiap variabel, jika rincian variabel yang ada pada tiap variabel mendapat tanggapan atau mengandung jawaban "Ya" maka diberikan poin "20". Jika rincian variabel yang ada pada tiap variabel tidak mendapat tanggapan atau mengandung jawaban "Tidak" maka diberikan poin "0" seperti dijelaskan dalam tabel 3.2: 
Tabel 3.2 Pembobotan Atribut

\begin{tabular}{|l|l|c|}
\hline \multicolumn{1}{|c|}{ Jawaban/Keterangan } & Penilaian/Skor \\
\hline Ya & $\begin{array}{l}\text { Apabila siswa terindikasi masuk kedalam salah } \\
\text { satu masalah }\end{array}$ & 20 \\
\hline Tidak & $\begin{array}{l}\text { Apabila siswa tidak terindikasi masuk kedalam } \\
\text { salah satu masalah }\end{array}$ & 0 \\
\hline
\end{tabular}

Untuk menentukan penilaian siswa terhadap masalah dengan kata "sering" ditentukan "Ya" apabila siswa tersebut melakukan 3 kali atau lebih terhadap satu masalah tersebut. Ditentukan "Tidak" apabila siswa tersebut melakukan 1 atau 2 kali terhadap satu masalah tersebut. Kemudian keseluruhan poin yang didapat dijumlahkan untuk menentukan kategori indikator penilaian akhir melalui konversi poin seperti pada Tabel 3.3 semakin tinggi poin yang didapat maka hasil penilaian pun akan kurang baik.

Tabel 3.3 Konversi Poin

\begin{tabular}{|l|l|}
\hline Total Poin & Hasil Penilaian \\
\hline 0 & Sangat Baik \\
\hline 20 & Baik \\
\hline 40 & Cukup Baik \\
\hline 60 & Cukup \\
\hline 80 & Kurang \\
\hline 100 & Kurang Sekali \\
\hline
\end{tabular}

4. Temuan Penelitian

a. Naïve Bayes

Untuk semua perhitungan nilai probabilitas dari data set Bimbingan Konseling dapat dilihat dalam tabel 4.1 dan berlaku untuk semua variabel, dengan contoh variabel "Masalah Masa Depan Pendidikan", adalah sebagai berikut dalam Tabel 4.1:

Tabel 4.1 Perhitungan Probablitias Naïve Bayes

\begin{tabular}{|c|c|c|c|c|}
\hline \multicolumn{2}{|c|}{ Masalah Masa Depan Pendidikan } & \multicolumn{2}{c|}{ Kelas } \\
\hline Sangat Baik & $\begin{array}{c}\text { Tidak Diharuskan } \\
\text { Konseling }\end{array}$ & $\begin{array}{c}\text { Diharuskan } \\
\text { Konseling }\end{array}$ & $\begin{array}{c}\text { Tidak Diharuskan } \\
\text { Konseling }\end{array}$ & $\begin{array}{c}\text { Diharuskan } \\
\text { Konseling }\end{array}$ \\
\hline Baik & 119 & 4 & 227 & 102 \\
\hline Cukup Baik & 72 & 12 & \\
\hline Cukup & 23 & 12 & \\
\hline Kurang & 13 & 43 & \\
\hline Kurang Sekali & 0 & 30 & \\
\hline & 0 & 1 & \\
\hline
\end{tabular}

Dari tabel 4.1 maka didapatkan hasil jumlah nilai probabilitas untuk atribut "Masalah Masa Depan Pendidikan", langkah selanjutnya membagi nilai dari tiap parameter dengan jumlah kelas yang sama. Total parameter "Sangat Baik" dengan Kelas "Tidak Diharuskan Konseling dibagi dengan jumlah kelas "Tidak Diharuskan Konseling" seperti dijelaskan dalam tabel 4.2: 
Tabel 4.2 Hasil Perhitungan Probablitias Naïve Bayes

\begin{tabular}{|c|c|c|}
\hline Parameter & Tidak Diharuskan Konseling & Diharuskan Konseling \\
\hline Sangat Baik & $119 / 227=0,524$ & $4 / 102=0,039$ \\
\hline Baik & $72 / 227=0,317$ & $12 / 102=0,118$ \\
\hline Cukup Baik & $23 / 227=0,101$ & $12 / 102=0,118$ \\
\hline Cukup & $13 / 227=0,057$ & $43 / 102=0,422$ \\
\hline Kurang & $0 / 227=0,000$ & $30 / / 202=0,294$ \\
\hline Kurang Sekali & $0 / 227=0,000$ & $1 / 102=0,010$ \\
\hline
\end{tabular}

\section{b. Naïve Bayes Berbasis Forward Selection}

Setelah dilakukan pengujian terhadap 10 variabel menggunakan algoritma Forward Selection menghasilkan atribut terpilih yang berpengaruh terhadap hasil klasifikasi, dari 10 attribut yang ada, terpilih 9 atribut yang signifikan dan 1 atribut dihilangkan seperti dijelaskan dalam tabel 4.3:

Tabel 4.3 Hasil Seleksi Atribut Menggunakan Algoritma Forward Selection

\begin{tabular}{|l|c|}
\hline \multicolumn{1}{|c|}{ attribute } & weight \\
\hline Masalah Hubungan Sosial dan Berorganisasi & 1 \\
\hline Masalah Keadaan Kehidupan Ekonomi & 1 \\
\hline Masalah Rekreasi dan Hobi & 1 \\
\hline Masalah Kehidupan Keluarga & 1 \\
\hline Masalah Agama dan Moral & 1 \\
\hline Masalah Kesehatan & 0 \\
\hline Masalah Pribadi & 1 \\
\hline Masalah Penyesuaian Sekolah & 1 \\
\hline Masalah Penyesuaian Terhadap Kurikulum & 1 \\
\hline Masalah Masa Depan Pendidikan & 1 \\
\hline
\end{tabular}

Dilihat dari nilai weight yang bernilai 1 (satu) artinya signifikan, dan nilai weight 0 artinya tidak signifikan atau atribut yang tidak berpengaruh, dalam hal ini atribut "Masalah Pribadi". hal ini menjelaskan bahwa dalam perhitungan bimbingan dan konseling dapat diprediksi secara optimal melalui 9 atribut yang dipilih melalui Forward Selection.

\section{c. Evaluasi}

Terlihat bahwa nilai accuracy Naïve Bayes berbasis Forward Selection lebih tinggi dibandingkan Naïve Bayes tunggal. Penerapan Forward Selection untuk seleksi atribut menghasilkan peningkatan akurasi sebesar $0.29 \%$, precision sebesar $0.26 \%$ dan recall sebesar $0.02 \%$ seperti dijelaskan dalam gambar 4.1: 


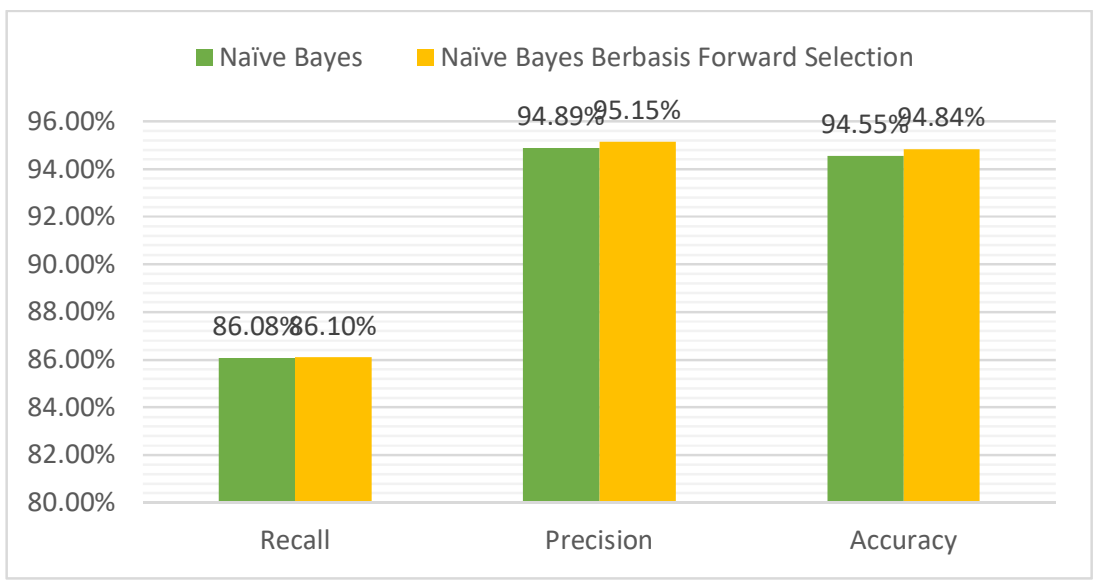

Gambar 4.1 Perbandingan hasil evaluasi

d. Perbandingan Algoritma yang diujikan dengan algoritma Naïve Bayes Berbasis Forward Selection

Berdasarkan hasil analisis dapat dibandingkan metode algoritma Naïve bayes berbasis Forward Selection lebih baik daripada hanya menggunakan metode Naïve Bayes saja dan juga akan dilakukan perbandingan terhadap fitur seleksi lain dalam hal ini yang digunakan adalah Backward Elimination. Tingkat akurasi pada prediksi menggunakan Forward Selection lebih baik daripada tidak menggunakan Forward Selection menunjukkan bahwa keberadaan fitur mempengaruhi hasil prediksi Gambar 4.5 membandingkan penggunaan metode Naïve Bayes, metode Naïve Bayes berbasis Forward Selection dan metode Naïve Bayes berbasis Backward Elimination Seperti dijelaskan dalam gambar 4.2:

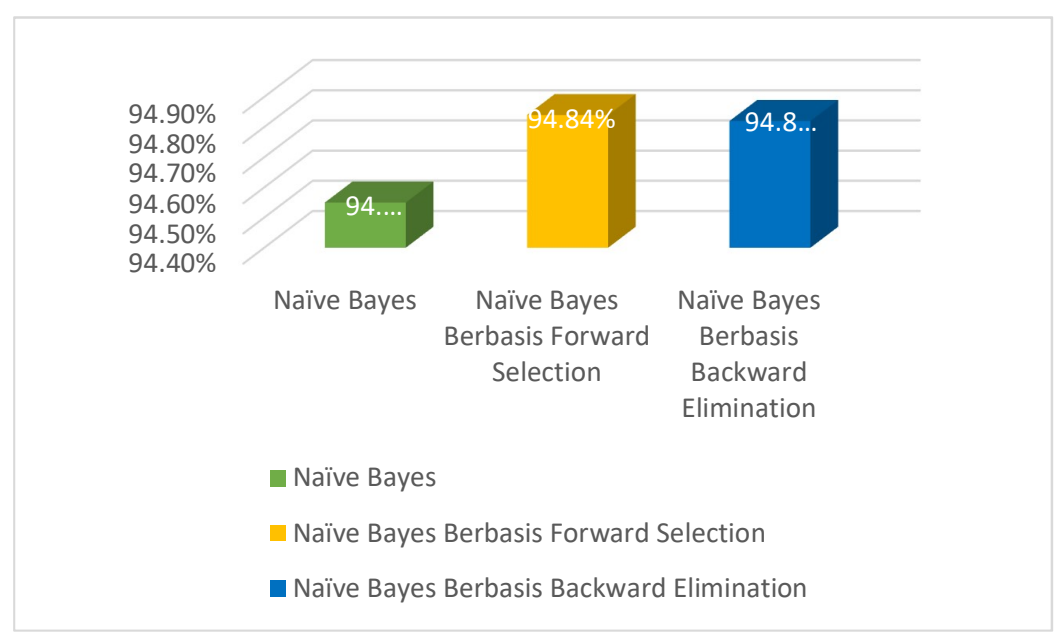

Gambar 4.2 Perbandingan algoritma yang diujikan dengan algoritma Naïve Bayes Berbasis Backward Elimination

\section{Kesimpulan dan Saran}

\section{a. Kesimpulan}

Dari hasil eksperimen dan evaluasi penelitian dapat disimpulkan bahwa akurasi metode Naïve Bayes pada bimbingan konseling siswa mencapai $94.55 \%$. setelah dilakukan penambahan fitur seleksi untuk memilih atribut yang relevan terhadap hasil klasifikasi didapatkan nilai akurasi yang lebih tinggi yaitu 94.84\%. Dari 10 variabel dari data Bimbingan 
Konseling Siswa terdapat 9 atribut yang signifikan, antara lain: "Masalah Hubungan Sosial dan Berorganisasi", "Masalah Keadaan Kehidupan Ekonomi", "Masalah Rekreasi dan Hobi", "Masalah Kehidupan Keluarga", "Masalah Agama dan Moral", "Masalah Kesehatan", "Masalah Penyesuaian Sekolah", "Masalah Penyesuaian Terhadap Kurikulum" dan "Masalah Masa Depan Pendidikan". Maka dapat disimpulkan pengujian data bimbingan dan konseling siswa menggunakan metode Naïve Bayes berbasis Forward Selection terbukti dapat meningkatkan tingkat akurasi dengan adanya penggunaan fitur seleksi tersebut, dibandingkan dengan metode Naïve Bayes tunggal, yang ditandai dengan peningkatan nilai akurasi sebesar $0.29 \%$.

\section{DAFTAR PUSTAKA}

Astuti, N. P., \& Arief, M. (2015). Analisis Prediksi TIngkat Ketidakdisplinan Siswa Menggunakan Algoritma Naive Bayes Classifier. Seminar Nasional Teknologi dan Informasi Multimedia. Sleman.

Bustami. (2014). Penerapan Naive Bayes untuk Menklasifikasi Data Nasabah Asuransi. Jurnal Informatika, VIII, 1-15.

Dash, M., \& Liu, H. (1997). Feature Selection for Classification. Intelligent Data Analysis, 131-156.

Gorunescu, F. (2011). Data Mining Concepts, Models, and Techniques. Berlin: Chennai.

Han, J., \& Kamber, B. (2006). Data Mining Concepts and Techniques. San Francisco: Diane Cerra.

Hermawati, L. (2015). Penggabungan Algoritma Backward Elimination dan Naive Bayes Untuk Mendiagnosis Penyakit Kanker Payudara. Teknik Informatika Vol. 11, 4245.

Kamaluddin, H. (2011). Bimbingan dan Konseling Sekolah. Jurnal Pendidikan dan Kebudayaan, 447-454.

Kholis, N. (2011). Pelaksanaan Bimbingan dan Konseling. Jurnal Ilmiah Pendidikan Bimbingan dan Konseling, 1-11.

Kohavi, R. (1995). A Study of Cross-Validation and Bootstrap for Accuracy Estimation and

\section{b. Saran}

Dari hasil pengujian yang telah dilakukan dan hasil kesimpulan yang diberikan maka ada saran atau usul yang di berikan antara lain:

a) Penelitian ini menggunakan klasifikasi yang menghasilkan dua kelas, selanjutnya bisa mengimplementasikan kalsifikasi Naïve Bayes dengan multiclass.

b) Untuk penelitian selanjutnya juga disarankan menggunakan atau menambahkan metode fitur seleksi yang lain seperti Particle Swarm Optimization yang digunakan juga untuk pembobotan atribut yang bisa meningkatkan akurasi untuk lebih mengoptimalkan kinerja algoritma klasifikasi.

Model Selection. Stanford: Artificial Intelligence.

Lieng, J., Kencana, I., \& Oka, T. (2014). Analisis Sentimen Menggunakan Metode Naive Bayes Classifier dengan Seleksi Fitur Chi Square. Jurnal Matematika Vol. 3, 92-99.

Nania, M., \& Purwanto. (2015). Metode KNearest Neighbor Berbasis Forward Selection Untuk Prediksi Harga Komoditi Lada. Jurnal Pseudocode Vol. II, 53-64.

Prabowo, D. R. (n.d.). Prediksi Nasabah yang Berpotensi Membuka Simpanan Deposito Menggunakan Naive Bayes Berbasis Particle Swarm Optimization. Jurnal Informatika, 1-10.

Reif, M., \& Shafait, F. (2014). Efficient Feature Size Reduction via Predictive Forward Selection. Pattern Recognition, 1664-1673.

Saraswati, N. (2011). Text Mining dengan Metode Naive Bayes Classifier dan Support Vector Machines untuk Sentiment Analysis. Denpasar: Universitas Udayana.

Sarjilah. (n.d.). Layanan Bimbingan Konseling di SMA. Yogyakarta: Widyaiswara LPMP.

Suwondo, \& Santoso, S. (2014). Credit Scoring Menggunakan Metode Support Vector Machine Dengan Teknik Seleksi Atribut Berbasis Chi Squared Statistic dan Particle Swarm Optimization. Jurnal Teknologi Informasi, 10 (1414-9999), 1-18. 